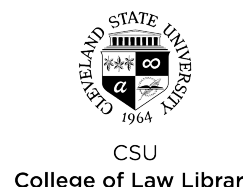

Journal of Law and Health

Volume 30 | Issue 1

Article

7-1-2017

\title{
Analysis of the Proposed TPP-Related Patent Linkage System in Taiwan
}

Ping-Hsun Chen

National Chengchi University

Follow this and additional works at: https://engagedscholarship.csuohio.edu/jlh

Part of the Chemical and Pharmacologic Phenomena Commons, Health Law and Policy Commons, Medical Jurisprudence Commons, Medicinal and Pharmaceutical Chemistry Commons, Pharmaceutical Preparations Commons, Pharmaceutics and Drug Design Commons, and the Pharmacy Administration, Policy and Regulation Commons

How does access to this work benefit you? Let us know!

\section{Recommended Citation}

Ping-Hsun Chen, Analysis of the Proposed TPP-Related Patent Linkage System in Taiwan, 30 J.L. \& Health 55 (2017) available at https://engagedscholarship.csuohio.edu/jlh/vol30/iss1/3

This Article is brought to you for free and open access by the Journals at EngagedScholarship@CSU. It has been accepted for inclusion in Journal of Law and Health by an authorized editor of EngagedScholarship@CSU. For more information, please contact library.es@csuohio.edu. 


\title{
ANALYSIS OF THE PROPOSED TPP-RELATED PATENT LINKAGE SYSTEM IN TAIWAN
}

\author{
PING-HSUN CHEN
}

ASSISTANT PROFESSOR, GRADUATE INSTITUTE OF TECHNOLOGY, INNOVATION AND INTELLECTUAL PROPERTY MANAGEMENT, NATIONAL CHENGCHI UNIVERSITY

J.D. 10' \& LL.M. 08', WASHINGTON UNIVERSITY IN ST. LOUIS SCHOOL OF LAW; LL.M. 07', NATIONAL CHENGCHI UNIVERSITY, TAIWAN; B.S. 97' \& M.S. 99' IN

Chem. Eng., NATIONAL TAIWAN University, TAiwan.

EMAIL: CSTR@NCCU.EDU.TW

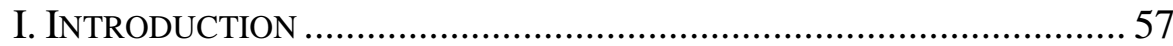

II. TPP IP CHAPTER AND PATENT LiNKAGE CLAUSE......................... 60

A. Prerequisite of Patent Linkage ....................................... 60

B. Patent Linkage System.................................................. 62

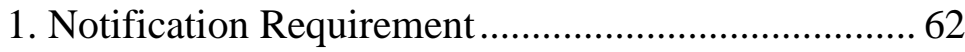

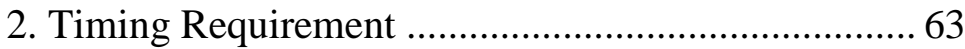

3. "Procedure and Remedy" Requirement .................... 63

C. Alternative to the Patent Linkage System........................ 65

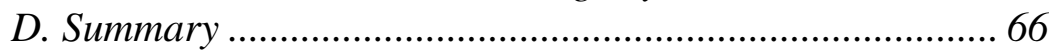

III. DRUG PERMIT APPLICATION UNDER THE PHARMACEUTICAL

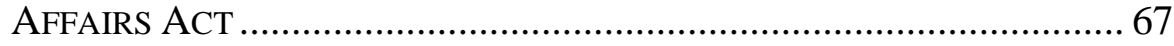

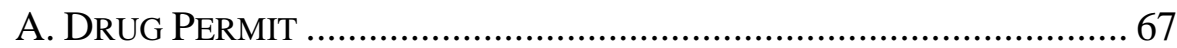

B. Submission of Test Data for a New Drug........................ 68

C. Disclosure of Patent Information..................................... 70

D. Test Data Protection ...................................................... 70

E. "Generic Drug Permit”" Application.............................. 71

IV. TAIWAN’s PROPOSED PATENT LINKAGE SYSTEM ........................ 71

A. Patent Information Submission ...................................... 71

B. Notification Made by a Generic Drug Permit Applicant .74

C. Stay of Issuance of a Drug Permit to a GDP Applicant .. 75

D. Exclusive Sales Period....................................................... 76

E. Anti-Competition Provision.......................................... 78

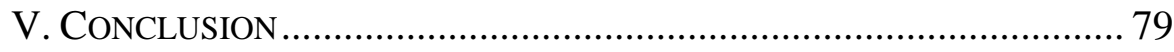




\section{Abstract}

The Trans-Pacific Partnership ("TPP”) Agreement mandates member states to implement a patent linkage system vested in Article 18.53. To successfully join the TPP Agreement, Taiwan has begun the legislation of a patent linkage system by proposing an amendment for the Pharmaceutical Affairs Act. Article 18.53 requires a member either to adopt a notification mechanism under Paragraph 1 or to stay the issuance of marketing approval under Paragraph 2. But, Taiwan's proposal includes both measures. Taiwan' patent linkage system allows a pioneer drug company to register patents claiming (a) a material; (b) a combination or formula; or (c) pharmaceutical use. The scope of patentees who may benefit from the mechanism is larger than what is required. In addition, the system requires a generic drug company to notify the patentee at the time of filing the drug application if the generic drug company asserts invalidity or non-infringement which the generic drug company must prove. Furthermore, the health authority is allowed to stay the issuance of a generic drug permit while the patentee is suing the generic drug company in the court. 


\title{
ANALYSIS OF THE PROPOSED TPP-RELATED PATENT LINKAGE SYSTEM IN TAIWAN
}

\author{
PING-HSUN CHEN
}

\begin{abstract}
ASSISTANT PROFESSOR, GRADUATE INSTITUTE OF TECHNOLOGY, INNOVATION AND InTELlECtUAl PROPERTY MANAGEMENT, NATIONAL CHENGCHI UNIVERSiTy
\end{abstract}

J.D. 10' \& LL.M. 08', WASHINGTON UNIVERSITY IN ST. LOUIS SCHOOL OF LAW; LL.M. 07', NATIONAL CHENGCHI UNIVERSITY, TAIWAN; B.S. 97' \& M.S. 99' IN ChEM. ENG., NATIONAL TAIWAN UNIVERSITY, TAIWAN.

EMAIL: CSTR@NCCU.EDU.TW

\section{INTRODUCTION}

The Trans-Pacific Partnership (“TPP”) Agreement was signed on February 4, 2016 in Auckland, New Zealand. ${ }^{1}$ Twelve countries, including Australia, Brunei, Canada, Chile, Japan, Malaysia, Mexico, New Zealand, Peru, Singapore, the United States and Vietnam, were involved in this multilateral free trade agreement ("FTA"). ${ }^{2}$

Like many FTAs, ${ }^{3}$ the TPP Agreement has an intellectual property chapter which is Chapter $18 .{ }^{4}$ Chapter 18 includes many provisions collectively setting a standard beyond the Agreement on Trade-Related Aspects of Intellectual Property Rights ("TRIPS Agreement"). ${ }^{5}$ Article 18.53 of the TPP Agreement is a highly-criticized

${ }^{1}$ See Rebecca Howard, Trans-Pacific Partnership Trade Deal Signed, but Years of Negotiations Still to Come, REUTERS, Feb. 4, 2016, http://www.reuters.com/article/us-trade-tppidUSKCN0VD08S (last visited Oct. 16, 2016); see also Kevin E. Noonan, The Trans-Pacific Partnership the Future of Global Trade or A Corporate Conspiracy Against Workers?, 8 LANDSLIDE 32, 32 (2016).

2 See Howard, supra note 1.

3 See Ping-Hsun Chen, Cross-Straits Economic Cooperation Framework Agreement, Cross-Strait Agreement on Intellectual Property Right Protection and Cooperation, and Implications of One-China, 36 Hous. J. INT'L L. 59, 66-67 (2014).

${ }^{4}$ See TPP Final Table of Contents, Office of the United States Trade Representative, https://ustr.gov/trade-agreements/free-trade-agreements/trans-pacific-partnership/tpp-full-text (last visited Oct. 16, 2016).

5 See Rupali Francesca Samuel, Drawn Up in Secret, the TPP's Text Helps Big Pharma Put Patents Over Patients, THE WIRE, (Nov. 16, 2015), http://thewire.in/15571/drawn-up-insecret-the-tpps-text-helps-big-pharma-put-patents-over-patients/ (last visited Oct. 16, 2016). 
provision that relates to "patent linkage."6 "Patent linkage" originates from the HatchWaxman Act of 1984..$^{7}$ The Hatch-Waxman Act established the Abbreviated New Drug Application ("ANDA") system which allows a pharmaceutical company to apply for a marketing approval of a generic version of a previously-approved drug without going through a full-scale experiment concerning the safety and efficacy of the generic drug. ${ }^{8}$ But, to compromise with the benefits of pioneer drug companies, the Hatch-Waxman Act created a cause of action for pioneer drug companies to sue those generic drug companies for patent infringement simply because of the filing of an ANDA. ${ }^{9}$ Australia, Canada, and Singapore also have a patent linkage system. ${ }^{10}$

While the TPP Agreement is under the national approval proceeding in each member state, Taiwan is eager to join the TPP Agreement. ${ }^{11}$ Among other things, the Executive Yuan ${ }^{12}$ announced a proposed amendment of the Pharmaceutical Affairs

${ }^{6}$ See Brook K. Baker \& Katrina Geddes, Corporate Power Unbound: Investor-State Arbitration of IP Monopolies on Medicines-Eli Lilly v. Canada and the Trans-Pacific Partnership Agreement, 23 J. INTELL. PROP. L. 1, 10, 10 n.43 (2015).

7 See Robert A. Armitage, The Hatch-Waxman Act: A Path Forward for Making It More Modern, 40 WM. Mitchell L. REV. 1200, 1201-03, 1235 (2014).

8 See Quincy (Ping-Hsun) Chen, Destroying A Pharmaceutical Patent for Saving Lives?: A Case Study of Sanofi-Synthelabo v. Apotex, Inc., 21 ALB. L.J. ScI. \& TeCH. 125, 136 (2011).

${ }^{9}$ See id. at 139-40.

10 See, e.g., Thomas A Faunce and Joel Lexchin, 'Linkage' Pharmaceutical Evergreening in Canada and Australia, Austl. \& N.Z. Health Pol'y, June 1, 2007, available at http://www.anzhealthpolicy.com/content/4/1/8 (last visited Oct. 16, 2016).

${ }^{11}$ See Tsai Appeals to US Leaders for TPP Support, TAIPEI TIMES, (Jul. 3, 2016), http://www.taipeitimes.com/News/taiwan/archives/2016/07/03/2003650248. Because the United States recently elected a new President, Donald Trump, who aggressively opposed the TPP Agreement during the campaign, the future of the TPP Agreement is very negative. See, e.g., Tim Worstall, With Trump"s Election the TPP Probably is Dead, Yes - As is the TTIP, FORBES, (Nov. 11, 2016_), http://www.forbes.com/sites/timworstall/2016/11/11/with-trumpselection-the-tpp-probably-is-dead-yes-as-is-the-ttip/\#18a9a7845b80 ; Sam Buckingham-Jones, Trans-Pacific Partnership Deal not Our Only Trade Option, Steve Ciobo Says, THE Australian, (Nov. 13, 2016), http://www.theaustralian.com.au/national-affairs/foreignaffairs/transpacific-partnership-deal-not-our-only-trade-option-steve-ciobo-says/newsstory/d0fa129210d05475a9bcd15df114539b. On the other hand, Japan's intent to approve the TPP Agreement right after the U.S. presidential election makes the issue more complicate. See, e.g., Japan's Parliament Approves TPP Deal, Labeled 'Disaster' by Trump, RT, (Nov. 10, 2016), https://www.rt.com/news/366367-japan-tpp-trump-china/; Japan Lawmakers Vote to Ratify TPP, Wall STREeT Journal, (Nov. 4, 2016), http://www.wsj.com/articles/japanlawmakers-vote-to-ratify-tpp-1478256900.

12 The Executive Yuan is the executive branch of the Taiwan Government. 
Act ${ }^{13}$ ("PAA") on August 4, 2016. ${ }^{14}$ The Proposed Amendment adds Chapter 4-1 governing a patent linkage system for generic drug permit ("GDP") applications. ${ }^{15}$ The Proposed Amendment has been submitted to the Legislative Yuan. ${ }^{16}$ The proposed patent linkage system forces a generic drug company to confront with patent law suits brought by a pioneer drug company. To do so, the Executive Yuan also introduced an amendment of the Patent Act. ${ }^{17}$ The Patent Act Amendment provides a cause of action for a pioneer company to sue a generic drug company if the latter company files a GDP application. ${ }^{18}$

This article is intended to explore the Proposed Amendment to figure out whether the Proposed Amendment follows Article 18.53 of the TPP Agreement or goes beyond the minimal protection on pioneer drug companies. To answer that question, it is necessary to interpret Article 18.53 to figure out the scope of protection. In this paper, Part II critically reviews Article 18.53 in light of the international law principles of treaty interpretation under Article 31(1) of the Vienna convention on the Law of Treaties ("VCLT"). Then, Part III introduces the current Pharmaceutical Affairs Act with respect to new drug applications and generic drug applications. The topics cover test data submission, patent information submission, and test data protection. Finally, Part IV analyzes the Proposed Amendment. The analysis covers the new system of patent information submission, notification mechanism, administrative action, and anti-competition.

13 It is also known as "yao-shi fa" (藥事法) in Mandarin. The official English text of the Pharmaceutical Affairs Act ("PAA") can be found at http://law.moj.gov.tw/Eng/LawClass/LawAll.aspx?PCode=L0030001, while the Mandarin version can be found at http://law.moj.gov.tw/LawClass/LawAll.aspx?PCode=L0030001. The current Pharmaceutical Affairs Act became effective on December 2, 2015 by Presidential Order hua zong yi yi No. 10400140921 (總統華總一義字第10400140921號令). When referring to any provisions of the PAA, this paper cites or quotes the official English text unless the author feels that the official translation cannot reflect the meaning of a provision.

${ }^{14}$ See Executive Yuan, Taiwan, The Executive Yuan Committee Passed a Proposed Amendment of the Pharmaceutical Affairs Act (Press Release), http://www.ey.gov.tw/News_Content2.aspx?n=F8BAEBE9491FC830\&s=B7A2785C56246F BA (in Mandarin) (last visited Oct. 16, 2016).

15 See Crystal J. Chen, Draft Amendment to Pharmaceutical Affairs Act Introduces Patent Linkage System and Revised Data Exclusivity, LEXOLOGY, (Oct. 31, 2016), http://www.lexology.com/library/detail.aspx?g=b50d0454-39c9-4694-a827-45d6d5acfe8d.

16 See Abraham Gerber, NHI Costs Would Rise with Law Changes: Opponents, TAIPEI Times, (Sept. 24, 2016), http://www.taipeitimes.com/News/taiwan/archives/2016/09/24/2003655834. The Proposed Amendment can be downloaded at http://lci.ly.gov.tw/LyLCEW/agenda1/02/pdf/09/02/01/LCEWA01_090201_00043.pdf.

17 See Crystal J. Chen, TIPO Proposed to Amend IP Laws Echoing Trans-Pacific Partnership Agreement, Lexology, (Aug. 5, 2016), http://www.lexology.com/library/detail.aspx?g=9a7b1ae4-2b62-42ab-8382-23a01f24e6f9 [hereinafter, Chen, TIPO Proposed].

18 See Chen, TIPO Proposed, supra note 17; see also Patent Act Amendment art. 60-1, para. 1. The Patent Act Amendment can be downloaded at http://lci.ly.gov.tw/LyLCEW/agenda1/02/pdf/09/02/01/LCEWA01_090201_00044.pdf （in Mandarin). 


\section{TPP IP CHAPTER AND PATENT LINKAGE CLAUSE}

Part II discusses the prerequisite of patent linkage and analyzes three requirements of the patent linkage system under the TPP Agreement. The analysis follows Article 31(1) of the VCLT which provides that "[a] treaty shall be interpreted in good faith in accordance with the ordinary meaning to be given to the terms of the treaty in their context and in the light of its object and purpose." 19 Accordingly, the TRIPS Agreement and Declaration on TRIPS and Public Health are interpretation tools. ${ }^{20}$ On the other hand, Article 31(2) of the VCLT further provides that " $[\mathrm{t}]$ he context for the purpose of the interpretation of a treaty shall comprise, in addition to the text, including its preamble and annexes: (a) any agreement relating to the treaty which was made between all the parties in connexion with the conclusion of the treaty[, $]^{21}$ but this paper does not consider those agreements made during the negotiations for the TPP Agreement because of the lack of publicly-accessible information.

\section{A. Prerequisite of Patent Linkage}

Article 18.53(1) sets only one condition as to when a member state shall provide a patent linkage system. Paragraph 1 recites:

[A] Party permits, as a condition of approving the marketing of a pharmaceutical product, persons, other than the person originally submitting the safety and efficacy information, to rely on evidence or information concerning the safety and efficacy of a product that was previously approved, such as evidence of prior marketing approval by the Party or in another territory[.] $]^{22}$

The condition has three elements. First, the marketing approval law requests an applicant to submit the safety and efficacy information of a pharmaceutical product. ${ }^{23}$ Second, an applicant may be permitted to rely on the safety and efficacy information previously submitted by other applicant. ${ }^{24}$ Third, the previously-submitted safety and efficacy information was used for the marketing approval of such prior applicant's product. ${ }^{25}$

\footnotetext{
19 Vienna Convention on the Law of Treaties art. 31(1) (1969) (emphasis added).

20 See TPP Agreement art. 18.6(1) ("The Parties affirm their commitment to the Declaration on TRIPS and

Public Health.").

21 Vienna Convention on the Law of Treaties art. 31(2) (1969) (emphasis added).

22 TPP Agreement art. 18.53(1).

23 TPP Agreement art. 18.53(1)(a).

24 TPP Agreement art. 18.53(1)(b).

25 TPP Agreement art. 18.53(1)(c).
} 
Therefore, the patent linkage system is not required if an applicant does not rely on any previously-submitted safety and efficacy information, or if an applicant relies on the safety and efficacy information of a pharmaceutical product that is not previously approved.

The patent linkage system under the TPP Agreement must be understood in the context of data protection. Patent linkage is applied after the term of test data protection. Under Article 18.50(1), if a previously-approved product is a new pharmaceutical product, any latter applicant is not permitted to rely on the safety and efficacy information of such previously-approved product for at least five years from the date of marketing approval of such previously-approved product. Under Article 18.52, a "new pharmaceutical product" in Article 18.50(1) means "a pharmaceutical product that does not contain a chemical entity that has been previously approved." 26 The term of test data protection for at least five years also applies to a new pharmaceutical product defined in Article 18.50(2)(b) as a pharmaceutical product that contains "a chemical entity that has not previously approved[.]"27

Under Article 18.51, the term of test data protection is at least eight years for a new pharmaceutical product "that is or contains a biologic," 28 or at least five years if other measures are also taken. ${ }^{29}$ A "biologic" is defined in Article 18.51(2) as to include "at a minimum, a product that is, or, alternatively, contains, a protein produced using biotechnology processes, for use in human beings for the prevention, treatment, or cure of a disease or condition." 30

After the term of test data protection, a member state may permit an applicant to rely on the safety and efficacy information of a previously-approved product. At that time, such applicant is subject to the patent linkage system. Therefore, the patent linkage system functions as an extension of data protection.

It should be noted that Article 18.53(1) does not require "a product that was previously approved" to be a new pharmaceutical product as Articles 18.50 and 18.51 do. ${ }^{31}$ But, in the context of generic drug applications, a person who originally submitted the safety and efficacy information that following generic drug companies rely on is more likely to be a right holder of the patents claiming the previouslyapproved product. ${ }^{32}$

\footnotetext{
26 TPP Agreement art. 18.52 (emphasis added).

27 TPP Agreement art. 18.50(2)(b).

28 See TPP Agreement art. 18.51(1)(a).

29 See TPP Agreement art. 18.51(1)(b). "Other measures" are not defined in the same

30 TPP Agreement art. 18.51(2).

31 TPP Agreement art. 18.53(1).

32 See Mark Gibson, Introduction and Perspective, in Pharmaceutical Preformulation AND FoRMULATION 1, 5 (Mark Gibson ed., Informa Healthcare USA 2009), available at http://basijmed.ir/public/vimb/books/foreign\%20books/Biopharmaceutical8.pdf (last visited Oct. 16, 2016)
} provision. 


\section{B. Patent Linkage System}

\section{Notification Requirement}

Article 18.53(1) sets three requirements for a patent linkage system. First, under Article 18.53(1)(a), a member state must establish "a system to provide notice to a patent holder or to allow for a patent holder to be notified prior to the marketing of such a pharmaceutical product, that such other person is seeking to market that product during the term of an applicable patent claiming the approved product or its approved method of use [.]"33 A member state may choose to treat a "patent holder" broadly as "a patent licensee or the authorized holder of marketing approval." 34

This notification requirement mandates the drug approval authority of a member state to establish a mechanism to inform a patent holder of marketing approval of a product associated with her patent. But, to be an eligible patent holder, the patent in question must claim the to-be-approved product or to-be-approved treatment. ${ }^{35} \mathrm{In}$ other words, the patent must be a pharmaceutical formula or a treatment through use of such pharmaceutical formula. However, in a member state which excludes from patentability "diagnostic, therapeutic and surgical methods for the treatment of humans" under Article 27(3)(a) of the TRIPS Agreement, ${ }^{36}$ an eligible patent may only be a patent claiming a pharmaceutical formula.

A patent claiming a pharmaceutical formula has a specific meaning. A pharmaceutical formula is a composition of active pharmaceutical ingredients and excipients. "Excipients" include four categories: (a) substances that "aid in the processing of the drug delivery system during its manufacture"; (b) substances that "protect, support or enhance stability, bioavailability or patient acceptability"; (c) substances that "assist in product identification"; (d) substances that "enhance any other attribute of the overall safety, effectiveness or delivery of the drug during storage or use." ${ }^{38}$ Thus, for purposes of patent linkage, an eligible drug patent must claim not only active pharmaceutical ingredients and excipients of the previously-approved drug, but also dosage forms thereof. ${ }^{39}$

33 TPP Agreement art. 18.53(1)(a) (emphasis added).

34 TPP Agreement chap. 18 n. 62.

35 Id.

36 See TRIPS Agreement art. 27(3)(a) (2017).

37 See Nishath Fathima et al., Drug-Excipient Interaction and its Importance in Dosage Form Development, 1 Journal of APPLIEd PhARMACEUTICAL SCIENCE 66, 66 (2011), available at http://www.japsonline.com/admin/php/uploads/125_pdf.pdf (last visited Oct. 16, 2016).

38 See International Pharmaceutical Excipients Council, The IPEC Excipient COMPOSITION GUIDE 2 (2009), available at http://ipeceurope.org/UPLOADS/IPECCompositionGuidefinal.pdf (last visited Oct. 16, 2016).

39 See Carlos Correa, Guidelines for the Examination of Pharmaceutical Patents: Developing a Public Health Perspective 6-9 (University of Buenos Aires, Working Paper 2006), available at http://www.ufrgs.br/antropi/lib/exe/fetch.php?media=correa_pharmaceuticalpatents-guidelines.pdf (last visited Oct. 16, 2016). 


\section{Timing Requirement}

The second requirement is the timing requirement. Article 18.53(1)(b) mandates a member state to provide "adequate time and opportunity for such a patent holder to seek, prior to the marketing of an allegedly infringing product, available remedies in subparagraph (c)[.]" 40 Three aspects may be added to the interpretation of Article 18.53(1)(b). First, the use of "seek" indicates that only a right to seek subparagraph (c) remedies is required, but actual granting of such remedies in every case is not mandatory. Second, the phrase "prior to the marketing of an allegedly infringing product" indicates that a right to seek available remedies in subparagraph (c) may be provided before the authority grants marketing approval or between the issue of marketing approval and actual marketing by the approval holder. That is, it is not required to stay the proceeding of marketing approval review before the patentee seeks mandatory remedies. Third, the "adequate time and opportunity" factor must be considered. Thus, it may not be adequate to avail the right to seek the required remedies just before the approval holder starts to market the allegedly infringing product.

\section{3. "Procedure and Remedy" Requirement}

The last requirement is the "procedure and remedy" requirement. Article 18.53(1)(c) demands "procedures, such as judicial or administrative proceedings, and expeditious remedies, such as preliminary injunctions or equivalent effective provisional measures, for the timely resolution of disputes concerning the validity or infringement of an applicable patent claiming an approved pharmaceutical product or its approved method of use." 41 That is, a member state must provide judicial or administrative proceedings. In those proceedings, an eligible patentee may move for either preliminary injunctions or equivalent effective provisional measures. The proceedings must be timely to resolve the issue of validity or infringement. However, a few questions remain.

The first question is whether there exists any infringing act during the marketing approval proceeding. If there is no infringing act, the only dispute will be validity. The interpretation of Article 18.53(1)(c) should not go that way. Otherwise, the term "infringement" would be void, which unlikely reflects the intent of the TPP Agreement. Thus, it is necessary to figure out which act is an infringing act during the marketing approval proceeding.

Under Article 28(1)(a) of the TRIPS Agreement, a patentee has exclusive rights to prevent others from making, using, offering for sale, selling, or importing for these purposes, her patented product. ${ }^{42}$ Or, under Article 28(1)(b) of the TRIPS Agreement, a holder of a process patent has a right to exclude others from using her patented

\footnotetext{
40 TPP Agreement art. 18.53(1)(b) (emphasis added).

41 TPP Agreement art. 18.53(1)(c).

42 See TRIPS Agreement art. 28(1)(a) ("A patent shall confer on its owner the following exclusive rights: (a) where the subject matter of a patent is a product, to prevent third parties not having the owner's consent from the acts of: making, using, offering for sale, selling, or importing for these purposes that product[.]").
} 
process. ${ }^{43}$ Because the TPP Agreement does not create any new exclusive rights, the rights of an eligible patent holder under the TPP Agreement are limited to Article 28(1) of the TRIPS Agreement. In addition, seeking a marketing approval may not be an act of infringement under Article 18.49 of the TPP Agreement. ${ }^{44}$ Therefore, the question becomes whether acquiring a marketing approval constitutes infringement.

A marketing approval holder has a right to market his approved drug. But, that is not equal to infringement. Marketing may mean advertising, events, knocking on doors, or direct mail..$^{45}$ In any case, a drug company markets its product because it wants to sell the product to targeted customers, such as doctors, hospitals, pharmacists, and patients. If a drug company merely promotes the availability of its product, there may be no infringement. But, if prices are in the marketing materials, such marketing act is more likely to constitute an "offer for sale" so as to infringe the patent. ${ }^{46}$ It is evident that a marketing approval holder will eventually offer a price of its drug to potential buyers. As a result, there is a potential threat to the patent holder. A timely resolution of the infringement issue is required when a marketing approval is granted. The issue of validity must be accompanied. Without a valid patent, there will be no infringement.

The second question is what "timely resolution" means. Although the TPP Agreement does not provide any clue, the phrase may be understood in light of Article 42 of the TRIPS Agreement. Article 42 requires that "[d]efendants shall have the right to written notice which is timely and contains sufficient detail, including the basis of the claims." $"$ Article 42 also provides that all parties "shall be duly entitled to substantiate their claims and to present all relevant evidence." 48 Therefore, the implementation of "timely resolution" should consider not only the interests of a patent holder, but also a marketing approval holder's right of due process.

The last question is the scope of "expeditious remedies." Article 18.53(1)(c) specifies "preliminary injunctions or equivalent effective provisional measures" as two categories of expeditious remedies. The use of "preliminary" and "provisional" indicates that those injunctions or measures are imposed before a court issues a final decision regarding whether the patent is infringed or whether the patent is valid. But,

43 See TRIPS Agreement art. 28(1)(b) ("A patent shall confer on its owner the following exclusive rights: ... (b) where the subject matter of a patent is a process, to prevent third parties not having the owner's consent from the act of using the process, and from the acts of: using, offering for sale, selling, or importing for these purposes at least the product obtained directly by that process.").

${ }^{44}$ See TPP Agreement art. 18.49 ("Without prejudice to the scope of, and consistent with, Article 18.40 (Exceptions), each Party shall adopt or maintain a regulatory review exception for pharmaceutical products.").

45 See John Burnett, Core Concepts of MArketing 3 (2008), available at http://www.saylor.org/site/wp-content/uploads/2012/11/Core-Concepts-of-Marketing.pdf (last visited Oct. 16, 2016).

46 See 3D Sys., Inc. v. Aarotech Labs., Inc., 160 F.3d 1373, 1379 (1998) ("As a matter of federal statutory construction, the price quotation letters can be regarded as 'offer[s] to sell' under $\S 271$ based on the substance conveyed in the letters, i.e., a description of the allegedly infringing merchandise and the price at which it can be purchased.” (alterations in original)).

47 TRIPS Agreement art. 42.

${ }^{48} \mathrm{Id}$. 
whether those expeditious remedies are mandatory is unclear. What factor has to be included in the consideration of those expeditious remedies is not listed in Article 18.53.

The availability of "expeditious remedies" may be determined in view of Article 18.50(3) of the TPP Agreement. Article 18.50(3) provides that a member state "may take measures to protect public health in accordance with: (a) the Declaration on TRIPS and Public Health[.]"49 Although the Doha Declaration on TRIPS and Public Health (hereinafter, "Doha Declaration") focuses on the issue of compulsory licensing, ${ }^{50}$ it emphases a balance between the importance of intellectual property protection for new drug development and the concerns on drug prices. ${ }^{51}$ Thus, public interests should be taken into consideration when expeditious remedies are implemented. This norm is also adopted in the United States as the Federal Circuit has held that " $[\mathrm{t}]$ o obtain a preliminary injunction, a party must show 'that it is likely to succeed on the merits, that it is likely to suffer irreparable harm in the absence of preliminary relief, that the balance of equities tips in its favor, and that an injunction is in the public interest." 52

In conclusion, the "procedure and remedy" requirement mandates procedures and expeditious remedies for a patent holder to resolve the issue of valid or infringement of her patent claiming the approved drug when the marketing approval is granted. But, the procedures must balance the interests of the patent holder and marketing approval holder. Public health must also be considered.

\section{Alternative to the Patent Linkage System}

Article 18.53(2) of the TPP Agreement establishes an alternative system to the patent linkage system under Article 18.53(1). Article 18.53(2) provides:

As an alternative to paragraph 1, a Party shall instead adopt or maintain a system other than judicial proceedings that precludes, based upon patentrelated information submitted to the marketing approval authority by a patent holder or the applicant for marketing approval, or based on direct coordination between the marketing approval authority and the patent office, the issuance of marketing approval to any third person seeking to market a pharmaceutical product subject to a patent claiming that product, unless by consent or acquiescence of the patent holder. ${ }^{53}$

49 TPP Agreement art. 18.50(3)(a).

50 See Declaration on the TRIPS Agreement and Public Health, World Trade Organization, DOHA WTO Ministerial (Nov. 14, 2001), I5, 41 I.L.M. 755 (2002) [hereinafter Doha Declaration], https://www.wto.org/english/thewto_e/minist_e/min01_e/mindecl_trips_e.htm (last visited Oct. 16, 2016).

51 See Id. at $\llbracket 4$.

${ }^{52}$ Luminara Worldwide, LLC v. Liown Elecs. Co., 814 F.3d 1343, 1352 (2016) (original alterations omitted).

53 TPP Agreement art. 18.53(2) (emphasis added). 
The phrase "an alternative to paragraph 1" indicates that a system under Article 18.53(2) is not mandatory but optional. The system is defined as a non-judicial proceeding, so it has to be an administrative proceeding. By stating that a drug authority "precludes, ..., the issuance of marketing approval," Article 18.53(2) does not require the authority to deny or reject the application for marketing approval. "Preclude" means "to make (something) impossible," "to prevent (something) from happening," or "to prevent (someone) from doing something." 54 Thus, Article 18.53(2) may merely require a stay of issuing a marketing approval.

Under Article 18.53(2), preclusion of the issuance of marketing approval may be based on the "patent-related information" submitted by a patent holder or marketing approval applicant. But, the definition of "patent-related information" is unclear. It may mean at least the information of patents as required in Article 18.53(1). In addition, preclusion may be based on "direct coordination" between the drug authority and patent authority. The second basis is more ambiguous because the TPP Agreement does not give any instruction on how two authorities may work together to conclude a decision of preclusion. Therefore, it is more difficult to implement Article 18.53(2) than Article 18.53(1).

It should be noted that by providing a system for a drug authority to preclude the issuance of marketing approval, Article 18.53(2) reaffirms that the timing for initiating the patent linkage system under Article 18.53(1) is the time of issuing a marketing approval. Otherwise, Article 18.53(2) is not distinct enough as to be an alternative to Article 18.53(1).

\section{Summary}

While the exact meaning of the "patent linkage" provision under the TPP Agreement is uncertain, the above analysis may provide some insights of how to implement the provision as follows:

(1) A patent linkage system is required only when an applicant for marketing approval relies on the safety and efficacy information of a previously-approved drug.

(2) To enjoy the benefits of patent linkage, an eligible patent holder must own a patent claiming a pharmaceutical formulation or method for using such pharmaceutical formulation. But, in a member state adopting Article 27(3)(a) of the TRIPS Agreement, only a person who holds a patent for a pharmaceutical formulation is eligible.

(3) A patent holder must be informed of the marketing approval of a drug covered by her eligible patent when the drug authority issues the approval.

(4) A procedure for the timely resolution of infringement or validity of the patentin-suit may be an administrative or judicial procedure. While the interests of a patentee are primarily concerned with, the procedure must consider a marketing approval holder's right of due process.

(5) A right to seek expeditious remedies, such as preliminary injunctions or equivalent effective provisional measures, is required. But, the grant of such remedies must consider public health issues.

(6) An alternative administrative procedure may be provided where the drug authority may preclude the issuance of marketing approval. Preclusion may be based

${ }^{54}$ See MERIAM-WEBSTER, http://www.merriam-webster.com/dictionary/preclude (last visited Oct. 16, 2016). 
on the patent-related information submitted by either a patent holder or marketing approval holder. The coordination between the drug authority and patent authority may also be a basis for preclusion.

\section{DRUg Permit APPLICATION UNDER the Pharmaceutical AfFairs ACT}

\section{A. Drug Permit}

The Pharmaceutical Affairs Act ("PAA") is a multi-task law governing drugs, medical devices, pharmaceutical companies, pharmacies and other relevant matters. ${ }^{55}$ The PAA is administrated by the Food and Drug Administration (hereinafter, "Taiwan FDA"). ${ }^{56}$ Chapter 4 of the PAA regulates the proceedings of registration and market approval of medicaments. Article 39 specifically provides the proceeding of approval of a “drug permit” (藥品許可證, yao-pin xu-ke zheng; hereinafter, “DP”). ${ }^{57}$ Paragraph 4 of Article 39 authorizes the Ministry of Health and Welfare to promulgate the Regulations for Registration of Medicinal Products ${ }^{58}$ ("Regulations") to review a DP. ${ }^{59}$ Without a DP, a company cannot manufacture or import drugs. ${ }^{60}$ An unlicensed

55 See PAA art. 1, para. 2 ("The term 'pharmaceutical affairs' used in the preceding Paragraph shall refer to medicaments, pharmaceutical firms, pharmacies and other relevant matters."); art. 4 ("The term 'medicaments' as used in this Act shall refer to drugs and medical devices.").

56 See About FDA, Food and Drug Administration, Ministry of Health and Wealth (June 6, 2006) http://www.fda.gov.tw/EN/aboutFDAContent.aspx?id=17\&chk=ec07b726-f665-4825ba5a-7d2387a299ad (last visited Oct. 16, 2016).

57 See PAA art. 39, para. 1 (“ For the manufacturing and import of drugs, information concerning the ingredients, source of active pharmaceutical ingredients, specifications, functions, summary of manufacturing process, and the specification and method of testing, as well as other related information and certificates, accompanied by labels and use instructions in the original and Chinese languages, and samples, together with the fee paid, shall be filed with the central competent health authority for registration and market approval. No manufacturing or importation of such drugs shall be allowed until a drug permit license is approved and issued.").

${ }^{58}$ It is also known as “yao-pin cha-yan deng-ji shen-cha zhun-ze” (藥品查驗登記審查準 則) in Mandarin. The official English text of the Regulations for Registration of Medicinal Products ("Regulations") can be found at http://law.moj.gov.tw/Eng/LawClass/LawContent.aspx?PCODE=L0030057, while the Mandarin version can be found at http://law.moj.gov.tw/LawClass/LawContent.aspx?PCODE=L0030057.

59 See PAA art. 39, para. 4 ("The application criteria, review procedure, approval criteria, and other matters to be complied with shall be established in the Regulations for Registration of Medicinal Products by the central competent health authority.").

60 See Id. at $\mathbb{P} 1$. 
drug is considered a fake or counterfeit drug. ${ }^{61}$ A person who manufactures, imports, or sells unlicensed drugs is criminally liable. ${ }^{62}$

\section{B. Submission of Test Data for a New Drug}

A "new drug" is defined in Article 7 of the PAA as "a drug which can be recognized through the examination of the central healthcare authority as a new compound, composition with a new therapeutic effect, or dosage form with a new administration." 63 Article 38-1 of the Regulations requires a "new drug permit" ("NDP") applicant for a new compound to submit test data of either of two categories.$^{64}$ The first-category data comes from Phase I conducted during the research period in Taiwan and Phase III simultaneously conducted in a foreign country. ${ }^{65}$ The second-category data comes from Phase II and Phase III conducted simultaneously in Taiwan and foreign country. ${ }^{66}$ The Regulations also provide the experimental requirements for Phases I, II, and III. ${ }^{67}$ Phase I is considered experimental in its nature and requires a pharmacokinetics study or pharmacodynamics study. ${ }^{68}$ In both studies, the number of tested people is at least ten in principle. ${ }^{69}$ Phase II is clinical testing where the number of tested people is at least twenty in principle. ${ }^{70}$ Phase III is known as a pivotal trial where the number of tested people is at least eighty in principle so as to sufficiently show that the test result in Taiwan is similar to that in the foreign country. ${ }^{71}$ The testing conditions of Phases I, II, or III may be modified by the Taiwan FDA. ${ }^{72}$ Tested people must be selected from Taiwanese people.

Alternatively, Article 38-2 of the Regulations allows an applicant to rely on drug approval issued by Germany, United States, United Kingdom, France, Japan, Switzerland, Canada, Australia, Belgium, or Sweden. ${ }^{73}$ But, the applicant is still required to submit clinical testing data of Phases I, II, and III. ${ }^{74}$ Phase I under Article

${ }^{61}$ See Id. art. 20 ("The term 'counterfeit drugs' as used in this Act shall refer to the drugs which are found to fall within any of the following circumstances after inspection or testing: 1 . The drugs are manufactured without prior approval[.]").

62 See Id. arts. $82,83$.

63 Id. art. 7.

${ }^{64}$ See Regulations for Registration of Medicinal Products art. 38-1 ("Regulations").

65 See Id. art. 38-1, para. 1.

66 See Id.

${ }^{67}$ See Id. 38-1, para. 2.

68 See Id.

69 See Id.

${ }^{70}$ See Id.

71 See Id.

72 See Id.

73 See Id. art. 38-2, para. 1.

${ }^{74}$ See Id. art. 38-2, para. 2. 
38-2 is the same as Phase I under Article $38-1 .^{75}$ Phases II \& III under Article 38-2 should be conducted in medical centers of multiple countries, but the number of tested Taiwanese people must meet either of two conditions. ${ }^{76}$ The first condition requires that the number for Phase II is at least twenty in principle and that number for Phase III is at least eighty in principle. ${ }^{77}$ The second condition requires in both Phase II and Phase III, the number of tested Taiwanese people should amount to at least ten percent of the total tested people around the different medical centers. ${ }^{78}$

In addition, Article 38-2 of the Regulations requires a second type of Phase III clinical data. ${ }^{79}$ While the second type should be conducted in medical centers of multiple countries, the countries must include one of Germany, United States, United Kingdom, France, Japan, Switzerland, Canada, Australia, Belgium, and Sweden. ${ }^{80}$ If the number of total tested people is above or equal to two hundreds, the number of Taiwanese tested people should be at least thirty in principle or amount to at least five percent of the total tested people. ${ }^{81}$ If the number of total tested people is below two hundreds, the number of Taiwanese tested people should be at least ten in principle. ${ }^{82}$ The testing conditions may be modified by the Taiwan FDA. ${ }^{83}$ Finally, the test report for the second type must have been submitted to the Food and Drug Administration of the United States and European Medicines Agency of the European Union as a reference for drug approval. ${ }^{84}$

Under Article 38-3, the testing data required by either Article 38-1 or Article 38-2 may be waived by the Taiwan FDA. ${ }^{85}$ But, the authority may require the submission of bridging study data. ${ }^{86}$

Currently, the examination of a drug permit application is not actually performed by the Taiwan FDA. Instead, the Taiwan FDA has delegated its power of examination to a non-governmental organization, the Center for Drug Evaluation ("CDE"). ${ }^{87}$ The

\footnotetext{
75 See Id.art. 38-1, para. 2 \& art. 38-2, para. 2.

76 See Regulations art. 38-2, para. 2.

77 See Id.

78 See Id.

${ }^{79}$ See Id.

80 See Id.

81 See Id.

82 See Id.

83 See Id.

${ }^{84}$ See Id.

85 See Regulations art. 38-3.

86 See Id.

${ }^{87}$ See About Us, Center for Drug Evaluation, http://www.cde.org.tw/eng/ ("The Center for Drug Evaluation (CDE) is a non-government and non-profit organization established by the Department of Health (now the Ministry of Health and Welfare, MOHW) to assist the Taiwan Food and Drug Administration (TFDA) in performing review of medical products and related
} services."). 
Taiwan FDA is an office receiving submissions, while the CDE examines the scientific validity of those submissions.

\section{Disclosure of Patent Information}

The disclosure of patents or patent applications related to an approved new drug is not mandatory under the PAA, while Article 40-2, Paragraph 1 requires the Taiwan FDA to publish publicly-disclosed patent numbers or patent application numbers submitted by a NDP applicant. ${ }^{88}$ Because the Taiwan FDA is required to publish the patent information of an approved drug, the Taiwan FDA has promulgated "an affidavit form of previously-disclosed patent numbers or patent application numbers" (已揭露專利字號/案號切結書, yi jie-lu zhuan-li zi-hao or an-hao qie-jie shu) ${ }^{89}$ In principle, a NDP applicant has to file such form when submitting her application for drug approval. However, not all applicants follow the Taiwan FDA's instruction. ${ }^{90}$

\section{Test Data Protection}

Article 40-2 of the PAA provides the protection on test data submitted by previous NDP applicants for a new compound. ${ }^{91}$ If the NDP holder of a previously-approved new compound has a marketing approval for the same compound in a foreign country, to enjoy the data protection, she must file a NDP application in three years from the issuance of her foreign marketing approval..$^{92}$ Article 40-2, Paragraph 2 prevents a latter applicant from relying on the test data of a previously-approved new compound for five years from the issuance of the drug permit for such new compound. ${ }^{93}$ However, Article 40-2, Paragraph 3 allows a drug permit application for a drug that has the same compound, same dosage form, same dosage, and same unit dose as a previously-approved drug has possessed. ${ }^{94}$ But, such Paragraph 3 application is permitted only after three years from the issuance of the NDP of such previouslyapproved new compound. ${ }^{95}$ Article 40-2, Paragraph 2 still applies to when a Paragraph 3 application may rely on the test data of a previously-approved new compound. ${ }^{96}$

88 See PAA art. 40-2, $\mathbb{1} 1$.

89 See Wei Shu Yao Zi, Ministry of Health And Wealth Order No. 0940330797 (Oct. 24, 2005), http://www.fda.gov.tw/pda/page01Content.aspx?id=1032\&chk=787b7135-d0b9467f-b572-9054f9a4af0d\&param=pn\%3D145.

90 See Regulations of Medicament Manufacturer Inspection, Food and Drug Administration, Ministry of Health and Welfare, http://www.fda.gov.tw/upload/133/2016081809343014308.xlsx.

91 PAA Art. 40.

92 See Id. art. 40-2, para. 4.

93 See Id. art. 40-2, para. 2.

${ }^{94}$ See Id. art. 40-2, para. 3.

95 See Id.

96 See Id. 


\section{E. “Generic Drug Permit” Application}

Although the PAA does not define a "generic drug," the Regulations do define a "generic drug" as a drug that has the same compound, same dosage form, same dosage, and same efficacy of a previously-approved drug. ${ }^{97}$ Therefore, in Article 40-2, Paragraph 3 of the PAA, a drug that has the same compound, same dosage form, same dosage, and same unit dose as a previously-approved drug may be considered as a generic version of such previously-approved drug. ${ }^{98}$ A Paragraph 3 application is a Taiwanese version of a generic drug application.

However, the PAA does not allow a GDP applicant to rely on her own test data. The Proposed Amendment does not change that. As analyzed in Part II, the prerequisite of the patent linkage system under Article 18.53 is that a GDP applicant relies on previously-submitted test data. ${ }^{99}$ If a GDP applicant chooses to submit his own test data, he is not subject to the patent linkage system. ${ }^{100}$ Therefore, the PAA and Proposed Amendment are not flexible to a generic drug company.

\section{TAIWAN’S PROPOSED PATENT LINKAGE SYSTEM}

The TPP Agreement requires a member state either to adopt a notification mechanism under Article 18.53(1) or to stay the issuance of marketing approval under Article 18.53(2). ${ }^{101}$ But, Taiwan's implementation of Article 18.53 includes a notification mechanism and allows the health authority to stay the issuance of a GDP. ${ }^{102}$ Whether the health authority may lift the stay depends on whether the patent dispute surrounding a GDP application is resolved in favor of the GDP applicant. ${ }^{103}$ Thus, Taiwan's patent linkage system provides broader protection than what is required under the TPP Agreement.

\section{A. Patent Information Submission}

The proposed patent linkage system starts with the provisions concerning "patentrelated information" mentioned in Article 18.53(2) of the TPP Agreement. ${ }^{104}$ Article 48-3 and Article 48-5 of the Proposed Amendment condition whether one may benefit from patent linkage on whether she timely submits patent information related to her NDP. ${ }^{105}$ Article 48-3, Paragraph 1 provides that "if a drug permit holder of a new drug thinks that it is necessary to submit the patent information of drug patents, she should prepare relevant documents and information and submit them to the central health

97 See Regulations for Registration of Medicinal Products Art. 4 (2015).

98 PAA Art. 40-2, II 3.

${ }^{99}$ See id.

100 See id.

101 See TPP Agreement art. 18.53.

102 Id.

103 Id.

104 Id.

105 PAA Arts. 48-3, 48-5. 
authority in forty five days starting from the next day of her receipt of a drug permit[.. ${ }^{1106}$ If she fails to submit the required patent information, Chapter 4-1 will not apply. ${ }^{107}$

On the other hand, Article 48-5 provides that "if a drug permit holder of a new drug acquires an invention patent examined and issued by the patent authority after her drug permit was granted by the central health authority and if such invention patent falls within the scope of drug patents under Article 48-3, Paragraph 2, she shall follow [Article 48-4] to submit the patent information in forty five days starting from the next day of the issuance of the patent." 108 If she fails to do so, Chapter 4-1 is not applicable. ${ }^{109}$

The Proposed Amendment also considers existing NDP holders' interests. ${ }^{110}$ Article 48-21 provides that when the Proposed Amendment becomes effective, an existing NDP holder may submit the required patent information under Article 48-4 in three months from the effectiveness of the Proposed Amendment. ${ }^{111}$

An eligible drug patent is defined in Article 48-3 as a patent claiming (a) a material; (b) a combination or formula; or (c) pharmaceutical use. ${ }^{112}$ The scope of "drug patents" under Article 48-3 makes the proposed patent linkage system TPP-Plus. ${ }^{113}$ The category of "material" patents covers any patent that claims a single ingredient of an approved drug. ${ }^{114}$ The scope of "single ingredients" covers not only active pharmaceutical ingredients but also excipients. ${ }^{115}$ On the other hand, an eligible patent under the TPP Agreement is a patent claiming the approved product composed of active pharmaceutical ingredients and excipients. ${ }^{116}$ Hence, the Proposed Amendment enlarges the scope of eligible patent holders beyond what is required by the TPP Agreement.

The required patent information of a drug patent is vested in Article 48-4. For each drug patent, a NDP holder basically has to submit three pieces of information: (a) the patent number; (b) the last date of the term of protection; (c) the patent owner's name or title, nationality, and residence, domicile or business place. ${ }^{117}$ If a drug patent claims pharmaceutical use of a drug, a NDP holder has to identify claim numbers. ${ }^{118}$ If a drug patent is licensed exclusively and if such exclusive license is recorded in the patent

\footnotetext{
106 PAA Art. 48-3, I[ 1.

107 See PAA Art. 48-3, II 1.

108 PAA Art. 48-5.

109 See id.

110 PAA Art. 48-21.

111 See id.

112 See id.

113 See PAA Art. 48-21.

${ }^{114} I d$.

115 Id.

116 See supra Part II.B.1.

117 See PAA Art. 48-4, II 1.

118 See id.
} 
authority, the (c) information of the exclusive licensee is required. ${ }^{119}$ If the owner or exclusive licensee of a drug patent does not reside, domicile, or have a business place in Taiwan, the (c) information of her agent is required. ${ }^{120}$ Last, if a NDP holder is not the owner or exclusive licensee of the drug patent, when submitting the required patent information, she should acquire a consent from the owner or exclusive licensee. ${ }^{121}$

The required patent information of a drug patent may be corrected by a NDP holder. ${ }^{122}$ Under Article 48-6, a NDP holder should apply for an amendment of patent information if any of the following conditions have occurred: (a) the patent authority grants and announces the extension of the term of protection; (b) the claims have been amended and published; (c) the revocation of the drug patent has been finalized; (d) the drug patent has expired; (e) the information of the patent owner, exclusive licensee, or agent has changed. ${ }^{123}$ If a NDP holder is not the owner or exclusive licensee of a drug patent, such amendment should be permitted by the patentee or exclusive licensee. ${ }^{124}$ Furthermore, a NDP holder is required to file an amendment in forty-five days from the next day of the occurrence of any of those five conditions. ${ }^{125}$ But, there is no negative consequence if she fails to do so.

The public may challenge the correctness of the required patent information. ${ }^{126}$ Article 48-7 provides that any person may notify the Taiwan FDA of any of the following incidents: (a) the documented drug patent has nothing to do with the approved drug; (b) the documented drug patent does not claim a material, combination or formula, or pharmaceutical use; (c) errors exist in the patent information; (d) the NDP holder fails to comply with Article 48-6. ${ }^{127}$ Such person should submit written reasons and evidence to support an Article 48-7 notification. ${ }^{128}$ Then, the Taiwan FDA should forward the notification to the NDP holder in twenty days from the next day of the filing of the notification. ${ }^{129}$ Next, the NDP holder should respond to the Taiwan FDA with written reasons, but the NDP holder is free to decide whether to file an amendment. ${ }^{130}$ In the end, the Taiwan FDA is not required to change the challenged information even if it is incorrect. ${ }^{131}$ Instead, the Taiwan FDA is only mandated to

\footnotetext{
119 See id.

120 See id.

121 See PAA Art. 48-4, II 2.

122 See id.

123 See id.

124 See PAA Art. 48-6, II 1.

125 See PAA Art. 48-6, II 2.

126 See PAA Art. 66.

127 See PAA Art. 48-7, II 1.

128 See id.

129 See PAA Art. 48-7, II 2.

130 See PAA Art. 48-7, II 3.

131 See PAA Art. 48-7.
} 
publish the information submitted by the challenger under Article 48-7 and the response submitted by the NDP holder. ${ }^{132}$

However, it is not to say that a NDP holder can document any patents he wants. Under Article 100-1, "if a drug permit holder of a new drug submits patent information as required by Articles 48-3 to 48-6 in a way of deception or falseness to the extent where criminal liability is involved, he should be transferred to the judicial authority for further proceedings." 133 Article 100-1 indicates that the falseness of the required patent information may cause a NDP holder to be held criminally liable. ${ }^{134}$ But, Article 100-1 does not specify any crimes that may be committed.

\section{B. Notification Made by a Generic Drug Permit Applicant}

Unlike the current PAA, the Proposed Amendment formally recognizes generic drug applications. While the Proposed Amendment does not define a "generic drug," it does use the term "generic drug permit" in several provisions related to the patent linkage system. ${ }^{135}$

Article 48-9 provides that "[w]hen applying for a drug permit, with respect to the patents documented by a [NDP] holder for the approved new drug, an applicant for a [GDP] should declare to the central health authority" any of the four situations. ${ }^{136}$ The first situation is that "no patent information is documented for such new drug." 137 The second situation is that "the patents corresponding to such new drug have expired." 138 When a declaration of the first or second situation is made, a GDP will be issued after the Taiwan FDA completes the examination of such GDP application and concludes that all requirements are satisfied. ${ }^{139}$ The third situation is that "after the patents corresponding to such new drug expired, the drug permit is issued by the central health authority." ${ }^{40}$ When a declaration of the third situation is made, even though all requirements are met, a GDP will not be granted until the documented patents expire. $^{141}$

The fourth situation is that "the patents corresponding to such new drug should be revoked, or the generic drug for the drug permit application does not infringe the patents corresponding to such new drug." 142 When a declaration of the fourth situation is made, the patent linkage system will be initiated. After a GDP application is filed, the Taiwan FDA will review whether the required data and information are

\footnotetext{
132 See PAA Art. 48-8.

133 PAA Art. 100-1.

134 See id.

135 See generally PAA.

136 See PAA Art. 48-9.

137 See id.

138 See id.

139 See PAA Art. 48-10.

140 See PAA Art. 48-9.

141 See PAA Art. 48-11.

142 See PAA Art. 48-9.
} 
complete. ${ }^{143}$ If the submitted data meets the requirements, the Taiwan FDA will serve a notification of completeness of data submission to the GDP applicant. ${ }^{144}$

When a declaration of the fourth situation is made, Article 48-12 requires a GDP applicant to serve a written notification to the NDP holder and Taiwan FDA in twenty days starting from the next day of the GDP applicant's receipt of the completeness notification. ${ }^{145}$ If the NDP holder does not own the patent or is not licensed exclusively, an Article 48-12 notification must also be served on the patentee or exclusive licensee. ${ }^{146}$ The written notification must include reasons and evidence of invalidity or non-infringement. ${ }^{147}$ If the GDP applicant fails to timely serve an Article 48-12 notification, the Taiwan FDA will reject the GDP application. ${ }^{148}$

As analyzed in Part II, the proper timing for a notification under Article 18.53(1) is the health authority's granting of marketing approval. ${ }^{149}$ But, the Taiwan's approach requires a notification to be delivered by a GDP applicant to a patentee or exclusive licensee when the GDP application is filed. ${ }^{150}$ The GDP applicant is also required to show why the patent at dispute is invalid or not infringed. ${ }^{151}$ That is, the burden of proof is imposed on the GDP applicant who is a potential patent infringer.

\section{Stay of Issuance of a Drug Permit to a GDP Applicant}

The Proposed Amendment introduces a mechanism where the Taiwan FDA may stay issuance of a drug permit to a GDP applicant. Under Article 48-13, the mechanism is controlled by the patentee or exclusive licensee. ${ }^{152}$ After the patentee or exclusive licensee receives an Article 48-12 notification, he must sue the GDP applicant for infringement of any documented patents in forty-five days starting from the next day of the receipt of the Article 48-12 notification. ${ }^{153}$ Article 48-13 further provides that the period of forty-five days runs from the receipt by the patentee or exclusive licensee, whoever receives the Article 48-12 notification later. ${ }^{154}$ The patentee or exclusive licensee must notify the Taiwan FDA of the filing of such law suit. ${ }^{155}$

Meanwhile, Article 48-13 mandates the Taiwan FDA not to issue a drug permit to the GDP applicant in fifteen months starting from the next day of the NDP holder's

\footnotetext{
143 See PAA Art. 48-12.

144 See id.

145 See PAA Art. 48-12, II 1.

146 See id.

147 See PAA Art. 48-12, II 2.

148 See PAA Art. 48-12, II 3.

149 TPP Agreement art. 18.53.

${ }^{150} \mathrm{Id}$.

151 Id.

152 See PAA Art. 48-13.

153 See PAA Art. 48-13, II 1.

154 See PAA Art. 48-13, II 3.

155 See PAA Art. 48-13, II 1.
} 
receipt of the Article 48-12 notification. ${ }^{156}$ But, the Taiwan FDA may issue a drug permit to the GDP applicant in any of the following situations ${ }^{157}$ :

(1) The patentee or exclusive licensee does not initiate a law suit during the required period of forty-five days.

(2) The law suit filed after the receipt of the Article 48-12 notification is not based on a patent documented under Article 48-3, 48-5, or 48-21 before the GDP application.

(3) Courts find that all patents disputed in the law suit should have been invalidated, or the GDP applicant wins a decision of non-infringement.

(4) All patents stated in the declaration of a fourth situation under Article 48-9 have been revoked by the Taiwan Intellectual Property Office.

(5) The patentee (or exclusive licensee) and GDP applicant have agreed to settle the dispute.

(6) All patents stated in the declaration of a fourth situation under Article 48-9 have expired.

If the patentee or exclusive licensee wins the law suit filed under Article 48-13 and if the winning decision is finalized in fifteen months starting from the next day of the NDP holder's receipt of the Article 48-12 notification, the Taiwan FDA is obligated under Article 48-13 not to issue a GDP until the patent at dispute expires. ${ }^{158}$ But, a stay under Article 48-13 is only implemented once. ${ }^{159}$ If the patent or exclusive licensee sues the same GDP applicant for the same generic drug again with a different documented patent not brought in the previous law suit, the Taiwan FDA will not stay issuance of a GDP. ${ }^{160}$

Last, while the Taiwan FDA must stay issuance of a GDP, it can continue the examination of the GDP application. ${ }^{161}$ Under Article 48-15, if the Taiwan FDA completes the examination, it should notify the GDP applicant. ${ }^{162}$ After receiving an Article 48-15 notification, the GDP applicant may file to the National Health Insurance Administration an application for inclusion of her drug product in the national health insurance system and for price determination ${ }^{163}$ But, the GDP applicant is not allowed to manufacture or import the generic drug until a GDP is issued. ${ }^{164}$

\section{Exclusive Sales Period}

The Proposed Amendment grants a period of exclusive sales to a GDP applicant who has made a declaration of the fourth situation under Article 48-9, if such applicant

\footnotetext{
156 See PAA Art. 48-13, II 2.

157 See id.

158 See PAA Art. 48-13, II 4.

159 See PAA Art. 48-14.

160 See id.

161 See PAA Art. 48-15.

162 See PAA Art. 48-15, II 1.

163 See PAA Art. 48-15, II 2.

164 See id.
} 
eventually gets a GDP. ${ }^{165}$ During the exclusive sales period, the Taiwan FDA is prevented from granting other GDPs for the same drug. ${ }^{166}$ But, it should be noted that under Article 48-20 a right of exclusive sales applies only if the drug under a GDP was a drug of a new compound. ${ }^{167}$ If the drug was a drug of a composition with a new therapeutic effect or a drug of a dosage form with a new administration, a right of exclusive sales does not exist. ${ }^{168}$

Under Article 48-16, a GDP holder whose data submission has been first considered complete by the Taiwan FDA will earn an exclusive sales period of twelve months. ${ }^{169}$ However, the calculation of the period does not start from the receipt of a GDP. Under Article 48-17, the period starts from actual sale of the products under such GDP. ${ }^{170}$ The exclusive GDP holder has to report the actual sale to the Taiwan FDA in twenty days starting from the next day of the actual sale. ${ }^{171}$ Then, the Taiwan FDA will determine the period including the starting date and expiration date. ${ }^{172}$

However, in the context of multiple GDP applicants, Article 48-16 provides that if the Taiwan FDA determines that more than one GDP applicants complete their data submission on the same day, these GDP applicants will share an exclusive sales period ${ }^{173}$ In addition, the calculation of the period starts from the earliest actual sale made by any of those GDP applicants. ${ }^{174}$

A GDP applicant who is supposed to enjoy an exclusive sales period may lose his right to exclusive sales, if any of the following three situations occurs with respect to his GDP application ${ }^{175}$ :

(1) During the examination of the GDP application, the declaration a fourth situation under Article 48-9 has been withdrawn.

(2) A notification of the completion of the examination is not received in twelve months starting from the next day of the completeness of the data submission.

(3) The patentee or exclusive licensee wins the law suit filed under Article 48-13, and the winning decision is finalized in fifteen months starting from the next day of the NDP holder's receipt of the Article 48-12 notification.

If the first GDP applicant loses a right to exclusive sales, other following GPD applicants for the same drug may earn such right. ${ }^{176}$ Article $48-16$ provides that the determination of which following GPD applicant inherits such right depends on the

\footnotetext{
165 See PAA Arts. 48-16, 48-17.

166 See PAA Art. 48-16, II 1.

167 See PAA Art. 48-20.

168 See id.

169 See PAA Art. 48-16, II 1.

170 See PAA Art. 48-17, II 2.

171 See PAA Art. 48-17, \I 2.

172 See id.

173 See PAA Art. 48-16, II 3.

174 See PAA Art. 48-17, II 3.

175 See PAA Art. 48-16, II 2.

176 See id.
} 
date on which their data submission is considered complete. ${ }^{177} \mathrm{~A}$ following GDP applicant who gets the earliest date wins the exclusive sales period. ${ }^{178}$

Last, Article 48-18 provides three situations where the Taiwan FDA may grant a GPD to other applicants without the concerns of the existing right of sales exclusivity ${ }^{179}$ First, the GDP applicant who is supposed to enjoy an exclusive sales period fails to acquire a GDP by a deadline required by the Taiwan FDA. ${ }^{180}$ Second, such GDP applicant has never reported the date of actual sale. ${ }^{181}$ Third, the patents listed in the declaration of the fourth situation under Article 48-9 have expired. ${ }^{182}$

The exclusive sales period seems to be negative to a pioneer drug company because a generic drug company may share the market. But, the exclusivity actually limits the competition the pioneer drug company will face. The pioneer drug company and its rival generic drug company co-exist without any business penetrations from other generic drug companies. That is an oligopoly where a small number of drug companies are in the market. ${ }^{183}$ Although the drug price may drop, it will not be as lower as what would be in perfect competition. ${ }^{184}$ Therefore, granting of an exclusive sales period is actually positive to a pioneer drug company.

\section{E. Anti-Competition Provision}

The Proposed Amendment mandates a duty to report an agreement among a NDP applicant, NDP holder, GDP applicant, GDP holder, eligible patentee or exclusive licensee, if such agreement involves Chapter 4-1 affairs including drug manufacturing, sales, and exclusive sales period. ${ }^{185}$ Article 48-19 requires parties of such agreement to report to the Taiwan FDA in twenty days starting from the next day of the signing date of such agreement. ${ }^{186}$ The way to report and the content of such report are subject to the regulations made by the Taiwan FDA. ${ }^{187}$ Failure to report such agreement may result in an administrative monetary penalty imposed on the parties to such agreement. ${ }^{188}$ Finally, if the Taiwan FDA determines that such agreement is more

\footnotetext{
177 See id.

178 See id.

179 See PAA Art. 48-18.

180 See id.

181 See id.

182 See id.

183 See Phillip Areeda, louis Kaplow, et Al, Antitrust Analysis: Problems, Text, AND CASES 13-14 (6th ed. 2004).

184 See id. at 14.

185 See PAA Art. 48-19.

186 See PAA Art. 48-19, II 1.

187 See PAA Art. 48-19, II 2.

188 See PAA Art. 92-1.
} 
likely to violate the Fair Trade Act, it will refer the case to the Fair Trade Commission for further proceedings. ${ }^{189}$

\section{CONCLUSION}

To prepare for joining the TPP Agreement, the Taiwan Government has begun to implement a patent linkage system required under Article 18.53 of the TPP Agreement. Taiwan' approach is a pro-patentee mechanism. The mechanism allows a NDP holder to register patents claiming (a) a material; (b) a combination or formula; or (c) pharmaceutical use. ${ }^{190}$ The scope of patentees who may benefit from the mechanism is larger than what Article 18.53 requires. In addition, the mechanism requires a GDP applicant to notify the NDP holder and patentee at the time of filing the GDP application when the applicant asserts no patents associated with the generic drug are valid or infringed. ${ }^{191}$ The mechanism forces the GDP applicant to prove invalidity or non-infringement. ${ }^{192}$ Furthermore, the mechanism allows the Taiwan FDA to stay the issuance of a GDP while the patentee is suing the GDP applicant in the court. ${ }^{193}$ Therefore, the proposed patent linkage system may be considered as TPPPlus.

\footnotetext{
189 See PAA Art. 48-19, II 3.

190 TPP Agreement art. 18.53.

191 Id.

192 Id.

${ }^{193} I d$.
} 